\title{
PENGARUH IMPLEMENTASI MODEL PROBLEM BASED LEARNING TERHADAP KETERAMPILAN BERPIKIR KRITIS PESERTA DIDIK PADA MUATAN IPS KELAS V SDN 30 AMPENAN
}

\author{
Lola Laswita $^{1, *)}$, Darmiany ${ }^{2)} \&$ Heri Hadi Saputra ${ }^{3)}$ \\ 1), 2), 3) Universitas Mataram, Mataram, Indonesia \\ E-mail: lola25ixc@gmail.com
}

\begin{tabular}{|c|c|}
\hline INFORMASI ARTIKEL & ABSTRAK \\
\hline $\begin{array}{l}\text { Riwayat Artikel } \\
\text { Received: August 25, } 2020 \\
\text { Revised: August 28, } 2020 \\
\text { Accepted: September } 5,2020 \\
\\
\text { Kata Kunci: } \\
\text { Problem Based Learning, } \\
\text { Keterampilan Berpikir Kritis, } \\
\text { Ilmu Pengetahuan Sosial }\end{array}$ & $\begin{array}{l}\text { Penelitian ini bertujuan untuk mengetahui pengaruh implementasi model } \\
\text { problem-based learning terhadap keterampilan berpikir kritis peserta didik } \\
\text { pada muatan IPS kelas V di SDN } 30 \text { Ampenan tahun pelajaran } 2019 / 2020 . \\
\text { Metode penelitian yang digunakan yaitu penelitian kuantitatif dengan jenis } \\
\text { ex-post facto. Populasi dalam penelitian ini adalah peserta didik kelas V SDN } \\
30 \text { Ampenan yang berjumlah } 68 \text { peserta didik. Adapun sampel yang } \\
\text { digunakan yaitu peserta didik kelas VA yang berjumlah } 35 \text { peserta didik. } \\
\text { Sampel dipilih dengan menggunakan teknik purposive sampling. Instrumen } \\
\text { dalam penelitian ini diukur menggunakan angket dan tes. Dalam pengujian } \\
\text { instrument, peneliti menggunakan uji validitas ahli, validitas isi, serta uji } \\
\text { reliabilitas. Adapun data model problem-based learning dikumpulkan } \\
\text { menggunakan angket pada peserta didik dengan perolehan sebesar } 80.86 \% \\
\text { dan termasuk dalam kategori keterlaksanaan baik. Sementara data } \\
\text { keterampilan berpikir kritis dikumpulkan menggunakan tes tulis dengan } \\
\text { perolehan nilai rata-rata rata-rata sebesar } 80,00 \text { dan termasuk dalam skala } \\
\text { interval kategori kritis. Sebelum melakukan uji hipotesis, terlebih dahulu } \\
\text { dilakukan uji prasyarat yakni uji normalitas dan linieritas data. Berdasarkan } \\
\text { uji hipotesis menggunakan uji-t (uji regresi linier sederhana) dengan taraf } \\
\text { signifikansi } 5 \% \text { diperoleh nilai signifikansi sebesar } 0,00 \text {. Dikarenakan nilai } \\
\text { signifikansi kurang dari (<) nilai probabilitas } 5 \% \text {, maka Ho ditolak dan Ha } H_{a} \\
\text { diterima. Hal ini menunjukkan bahwa ada pengaruh implementasi model } \\
\text { problem-based learning terhadap keterampilan berpikir kritis peserta didik } \\
\text { pada muatan IPS kelas V di SDN } 30 \text { Ampenan Tahun Pelajaran } 2019 / 2020 .\end{array}$ \\
\hline
\end{tabular}

\section{A. PEndahuluan}

Pendidikan adalah usaha sadar dan terencana untuk mewujudkan suasana belajar dan proses pembelajaran agar peserta didik secara aktif mengembangkan potensi dirinya sehingga memiliki kekuatan spiritual keagamaan, pengendalian diri, kepribadian, kecerdasan, akhlak mulia, serta keterampilan yang diperlukan oleh dirinya, masyarakat, bangsa dan negara. Sistem pendidikan di Indonesia kini telah menerapkan Kurikulum 2013 yang diharapkan membawa perubahan pada pelaksanaan paradigma pembelajaran di sekolah. Pendidikan yang berkualitas tidak terlepas dari peran guru yang profesional yang mampu melibatkan peserta didik secara aktif dalam proses pembelajaran yang mengarah pada terbentuknya nilai-nilai yang dibutuhkan peserta didik dalam kehidupan (Maulyda et al., 2020). 
Terfokus dalam kehidupan sehari-hari, salah satu muatan pembelajaran yang sangat tepat dan penting untuk dibelajarkan adalah muatan IPS. Pembelajaran IPS sangat penting diberikan kepada peserta didik pada jenjang sekolah dasar sebab peserta didik sebagai anggota dalam masyarakat sangat perlu mengenal masyarakat dan lingkungannya. Hal tersebut sejalan dengan hakikat ilmu pengetahuan sosial yakni menelaah tentang manusia dan lingkungannya. Menurut Wahyudi (dalam Hidayati dkk, 2008:11), IPS adalah mata pelajaran yang menelaah masalah-masalah yang terjadi di masyarakat dengan perkembanagan ilmu pengetahuan, teknologi, dan komunikasi.

Dalam proses pembelajaran khususnya pada muatan IPS di SD sejauh ini masih di dominasi pada sebuah pembelajaran yang menuntut fakta-fakta yang harus dihafal sehingga peserta didik dapat terbebani oleh materi yang harus dikuasai. Berkaitan dengan proses pembelajaran pada muatan Ilmu Pengetahuan Sosial (IPS), pembelajaran di sekolah sudah seharusnya dapat berperan penting dalam mengembangkan keterampilan berpikir peserta didik. Guru seharusnya dapat merangsang keterampilan berpikir peserta didik dalam proses memecahkan suatu masalah ataupun mengidentifikasi gejala sosial yang ada. Muatan pembelajaran IPS yang cukup luas membutuhkan kreativitas dan menuntut ketepatan guru dalam menentukan model pembelajaran yang mampu mengembangkan keterampilan berpikir peserta didik.

Berpikir kritis merupakan bagian dari kegiatan berpikir yang dilakukan otak secara sistematis (Maulyda et al., 2019). Wijaya (2010:72) mengungkapkan bahwa berpikir kritis merupakan kegiatan menganalisis ide atau gagasan ke arah yang lebih spesifik, membedakannya dengan tajam, memilih, mengidentifikasi, mengkaji dan mengembangkan ke arah yang lebih sempurna. Kemampuan berpikir kritis dan dan berpikir kreatif merupakan ciri utama dari kemampuan berpikir tingkat tinggi (Erfan \& Ratu, 2018). Berpikir kritis akan memicu suatu proses sistematis yang memungkinkan peserta didik untuk merumuskan dan mengevaluasi keyakinan dan pendapat mereka sendiri (Nugraha, 2018: 120). Guru sebagai fasilitator harus memiliki kemampuan dalam mengemas proses pembelajaran yang menarik, salah satunya ketepatan penggunaan model pembelajaran. Pemilihan model pembelajaran yang tepat akan memperjelas konsep-konsep yang diberikan sehingga peserta didik senantiasa turut berperan aktif dan antusias dalam berpikir, bukan hanya menghafal.

Berdasarkan hasil observasi dan wawancara yang dilakukan dengan guru kelas $\mathrm{V}$ di SDN 30 Ampenan, dalam kurikulum 2013 ini terutama pada muatan pembelajaran IPS salah satu guru kelas $\mathrm{V}$ sudah pernah menerapkan model pembelajaran yang dapat membantu proses analisis peserta didik, seperti salah satunya yakni model problem-based learning. Melalui 
penerapan problem-based learning diharapkan tujuan pembelajaran dapat tercapai dengan optimal. Selain itu melalui model pembelajaran ini peserta didik terlihat lebih aktif dalam proses pembelajaran.

Menurut Siswono (dalam Assegaff, dkk 2016) Problem Based Learning adalah suatu pendekatan pembelajaran yang dimulai dengan mengajukan masalah dan dilanjutkan dengan menyelesaikan masalah tersebut. Delisle (dalam Abidin, 2014:159), juga menjelaskan bahwa "problem-based learning merupakan sebuah model pembelajaran yang dikembangkan untuk membantu guru mengembangkan kemampuan berpikir dan keterampilan memecahkan masalah pada siswa selama mereka mempelajari materi pembelajaran". Dalam penerapan model Problem Based Learning peserta didik diberikan kebebasan dalam berpikir serta aktif berpastisipasi dalam mengembangkan penalarannya pada materi yang diajarkan kemudian mampu mengimplementasikan penalarannya dalam memecahkan masalah di kehidupan seharihari. Selain itu, kelebihan dari penerapan model problem-based learning beberapa diantaranya adalah mampu mendorong peserta didik untuk mampu berpikir tingkat tinggi dan mengembangkan motivasi belajar peserta didik serta melatih peserta didik untuk belajar mandiri.

Adapun penelitian ini didukung oleh penelitian yang relevan. Pertama, penelitian yang telah dilakukan oleh Diana Kholida (2015) yang bertujuan untuk mengetahui pengaruh penggunaan model pembelajaran problem-based learning terhadap motivasi belajar siswa. Penelitian tersebut menggunakan metode kuantitatif Ex post-facto. Adapun hasil penelitian ini adalah ada pengaruh penggunaan model pembelajaran problem-based learning terhadap motivasi belajar siswa di Madrasah Aliyah Negeri 2 Jepara dengan perolehan besarnya pengaruh untuk kelas XI IPS1 sebesar 25,7\% dan untuk kelas XI IPS2 sebesar 28,5\%, selebihnya dipengaruhi oleh faktor lain.

Kedua, penelitian yang dilakukan oleh Sukroni (2014) yang bertujuan untuk mengetahui pengaruh model problem-based learning terhadap keterampilan berpikir kritis siswa SDN 1 Sajira pada mata pelajaran IPA. Metode penelitian tersebut adalah quasi eksperimen. Hasil penelitian menunjukkan bahwa terdapat pengaruh model PBL terhadap keterampilan berpikir kritis siswa pada mata pelajaran IPA konsep ekosistem. Hal tersebut ditunjukkan dari hasil perbandingan nilai rata-rata hasil pre-test maupun post-test yang diperoleh kelas eksperimen terjadi peningkatan yang signifikan.

Ketiga, hasil penelitian yang dilakukan oleh Rifka Anisaunnafi'ah (2015) dengan bertujuan untuk mengetahui pengaruh model problem-based learning terhadap motivasi 
Laswita, dkk. (2020). Pengaruh Implementasi Model...

belajar IPS. Penelitian yang dilakukan merupakan quasi experiment. Hasil penelitian menunjukkan bahwa terdapat pengaruh model problem-based learning terhadap motivasi belajar IPS dengan hasil perhitungan rata-rata skor skala motivasi pada kelas eksperimen lebih besar dari kelas kontrol.

Peran guru menjadi faktor yang cukup penting dalam mengembangkan keterampilan berpikir kritis peserta didik. Ketepatan penggunaan suatu model pembelajaran sangat penting diperhatikan. Beragam model pembelajaran dapat diterapkan dalam proses pembelajaran di kelas, salah satunya dengan menerapkan model Problem Based Learning. Melalui model pembelajaran ini, peserta didik diharapkan dapat belajar mandiri dengan mengkonstuk ide atau gagasannya sendiri yang diintegrasikan pada kehidupan nyata sehingga mampu memecahkan masalah yang kompleks. Pesera didik akan terlibat aktif dalam proses pembelajaran sehingga pembelajaran akan lebih bermakna.

\section{B. METODE PENELITIAN}

Metode yang digunakan dalam penelitian ini adalah penelitian kuantitatif. Jenis penelitian yang digunakan yaitu penelitian ex-post facto. Syamsuddin dan Vismaia (2011: 164) yang menjelaskan bahwa penelitian ex-post facto merupakan penelitian yang variabel-variabel bebasnya telah terjadi sehingga perlakuan atau treatment tidak dilakukan pada saat penelitian berlangsung.

Penelitian ini memuat satu variabel bebas yakni model problem-based learning dan satu variabel terikat yakni keterampilan berpikir kritis. Dalam penelitian ini peneliti mencari tahu tentang pengaruh implementasi model problem-based learning pada suatu pembelajaran terhadap keterampilan berpikir kritis peserta didik. Dimana variabel bebas $(\mathrm{X})$ dalam penelitian ini secara keseluruhan sudah terjadi sehingga peneliti tidak memberikan perlakukan atau treatment pada saat peneliti mulai melakukan pengamatan terhadap variabel terikat (Y).

Penelitian dilakukan di Kelas V SDN 30 Ampenan. Populasi adalah keseluruhan subjek penelitian (Arikunto, 2010:173). Populasi dalam penelitian ini adalah peserta didik kelas V SDN 30 Ampenan yang berjumlah 68 peserta didik. Sampel adalah bagian dari jumlah dan karakteristik yang dimiliki oleh populasi tersebut Sugiyono (2018:120). Adapun teknik yang digunakan peneliti adalah sampling purposive. Sampling purposive merupakan teknik penentuan sampel dengan pertimbangan tertentu (Sugiyono, 2018:126). Pengambilan sampel dengan teknik tersebut dijadikan acuan dan dipilih berdasarkan hasil wawancara singkat yang peneliti lakukan langsung dengan guru kelas V SDN 30 Ampenan yang terdiri dari dua kelas yakni guru kelas VA dan VB. Berdasarkan diskusi dan wawancara didapatkan bahwa guru 
kelas VA yang sudah pernah menerapkan model problem based learning dalam pembelajaran sehingga dengan pertimbangan tersebut, maka peserta didik kelas VA yang berjumlah 35 peserta didik dijadikan sampel dalam penelitian ini.

Metode pengumpulan data yang digunakan dalam penelitian ini adalah angket, tes dan dokumentasi. Adapun instrument yang digunakan yakni lembar angket dan tes tulis dalam bentuk soal uraian (essay). Angket (kuesioner) dalam penelitian ini digunakan untuk mengetahui respon atau tanggapan peserta didik terkait keterlaksanaan pembelajaran yang telah diterapkan menggunakan model problem-based learning. Tes berupa tes essay (uraian) digunakan untuk mengukur keterampilan berpikir kritis peserta didik. Sebelum melakukan uji hipotesis, peneliti terlebih dahulu melakukan uji prasyarat yakni uji normalitas dan linieritas data. Teknik analisis data yang digunakan adalah uji hipotesis menggunakan bantuan program analisis statistik SPSS 21.0 for Windows dengan uji-t (uji koefisien regresi sederhana). Analisis uji-t digunakan untuk mengetahui apakah variabel bebas berpengaruh secara signifikan terhadap variabel terikat (Priyatno, 2010: 59). Dasar pengambilan keputusan dalam penelitian ini mengacu pada perbandingan nilai signifikansi dengan nilai probabilitas 0,05. Artinya jika nilai signifikansi $<0,05$ maka $\mathrm{H}_{0}$ ditolak dan $\mathrm{H}_{\mathrm{a}}$ diterima. Namun jika nilai signifikasi $>0,05$ maka $\mathrm{H}_{0}$ diterima dan $\mathrm{H}_{\mathrm{a}}$ ditolak. Sementara untuk melihat besarnya pengaruh variabel $\mathrm{X}$ terhadap variabel Y yang artinya untuk mengetahui besarnya pengaruh implementasi model problem-based learning terhadap keterampilan berpikir kritis peserta didik pada penelitian ini mengacu pada nilai koefisien determinasi atau R Square yang diperoleh berdasarkan hasil uji regresi linier sederhana.

\section{HASIL DAN PEMBAHASAN}

Penelitian ini dilaksanakan pada tanggal 16 sampai 18 Juli 2020. Penelitian ini dilakukan untuk mengetahui pengaruh implementasi model problem-based learning terhadap keterampilan berpikir kritis peserta didik pada muatan IPS kelas V di SDN 30 Ampenan. Data dalam penelitian ini yaitu model problem-based learning dan keterampilan berpikir kritis peserta didik.

\section{Implementasi Model Problem-Based Learning}

Data implementasi model problem-based learning pada kelas V di SDN 30 Ampenan ini diperoleh melalui angket bentuk tertutup dengan model skala guttman bentuk checklist. Berdasarkan hasil uji ahli dan kemudian hasil uji-coba lapangan, terdapat 10 butir angket yang valid untuk dapat digunakan dalam penelitian. Butir angket yang telah valid tersebut disebarkan kepada seluruh peserta didik yang menjadi sampel dalam penelitian ini yaitu kelas VA yang 
Laswita, dkk. (2020). Pengaruh Implementasi Model...

berjumlah 35 peserta didik. Berikut ini adalah tabel persentase implementasi model problembased learning.

Tabel 1. Persentase Implementasi Model Problem-based learning

\begin{tabular}{cccc}
\hline Jumlah Sampel & Jumlah Nilai & Jumlah Nilai Maksimal & Persentase \\
\hline 35 & 2830 & 3500 & 80,86 \\
\hline
\end{tabular}

Berdasarkan Tabel 1, diperoleh persentase respon peserta didik terkait implementasi model PBL sebesar $80,86 \%$. Berdasarkan kualifikasi keterlaksanaan pembelajaran menurut Sudjana (2005: 118), perolehan persentase tersebut dinyatakan telah berkategori keterlaksanaan baik.

\section{Keterampilan Berpikir Kritis}

Data keterampilan berpikir kritis peserta didik kelas V SDN 30 Ampenan ini diperoleh dari hasil tes tulis berbentuk soal uraian (essay). Butir soal yang telah divalidasi terdiri dari 5 butir soal yang disebarkan kepada seluruh peserta didik yang menjadi sampel dalam penelitian ini yaitu kelas VA yang berjumlah 35 peserta didik. Berdasarkan data yang terkumpul, diperoleh bahwa nilai maksimum hasil tes berpikir kritis peserta didik adalah 100 dan nilai minimum adalah 65. Jumlah sampel penelitian sebanyak 35 peserta didik, dengan total nilai sebesar 2800 sehingga diperoleh nilai rata-rata (mean) sebesar 80,00. Berikut tabel nilai ratarata (mean) dari tes berpikir kritis peserta didik.

Tabel 2. Nilai rata-rata (mean) Berpikir Kritis Peserta Didik

\begin{tabular}{ccc}
\hline Jumlah Sampel Penelitian & Total Nilai & Nilai Rata-Rata (Mean) \\
\hline 35 & 2800 & 80,00 \\
\hline
\end{tabular}

Pada Tabel 2, diperoleh nilai rata-rata (mean) sebesar 80,00. Perolehan nilai rata-rata (mean) tersebut masuk dalam berkategori kritis.

Tabel 3. Hasil Uji Hipotesis Data Model PBL dan Katerampilan Berpikir Kritis Peserta Didik

\begin{tabular}{ccccccc}
\hline Model & & \multicolumn{2}{c}{$\begin{array}{c}\text { Unstandardized } \\
\text { Coefficients }\end{array}$} & $\begin{array}{c}\text { Standardized } \\
\text { Coefficients }\end{array}$ & T & \multirow{2}{*}{ Sig. } \\
\cline { 3 - 5 } & & B & Std. Error & Beta & \\
\hline 1 & (Constant) & 29.364 & 6.593 & & 4.454 & .000 \\
& PBL & .626 & .081 & .803 & 7.729 & .000 \\
\hline
\end{tabular}

Berdasarkan hasil pengujian, menunjukkan bahwa nilai signifikan model PBL (problem-based learning) diperoleh sebesar 0,000. Dikarenakan nilai signifikansi 0,00<0,05 
maka dapat ditarik kesimpulan $\mathrm{H}_{0}$ ditolak dan $\mathrm{H}_{\mathrm{a}}$ diterima, sehingga dinyatakan bahwa ada pengaruh implementasi model problem-based learning terhadap keterampilan berpikir kritis peserta didik pada muatan IPS kelas V di SDN 30 Ampenan Tahun Pelajaran 2019/2020. Kemudian untuk melihat berapa besar pengaruh implementasi model PBL terhadap keterampilan berpikir kritis peserta didik dapat mengacu pada koefisien determinasi (R Square) yang diperoleh sebesar 0,644 yang mengandung pengertian bahwa persentase pengaruh variabel bebas (model problem-based learning) terhadap variabel terikat (keterampilan berpikir kritis) adalah sebesar 64,4\%, sementara sisanya 35,65 dipengaruhi oleh variabel atau faktor lain.

Hal ini diperkuat dari data hasil penelitian pada keterampilan berpikir kritis peserta didik dimana peneliti dengan bantuan guru menyebarkan 5 soal berpikir kritis pada muatan IPS dengan indikator (1) menganalisis, (2) mengevaluasi, (3) memecahkan masalah, hingga (4) membuat kesimpulan, didapatkan bahwa peserta didik sudah mampu menguraikan jawabannya dengan baik dapat dilihat dari nilai rata-rata (mean) keterampilan berpikir kritis yang diperoleh peserta didik sebesar 80,00 dan termasuk dalam kategori kritis. Berdasarkan nilai rata-rata (mean) keterampilan berpikir kritis peserta didik yang diperoleh tersebut, memberikan bukti pula bahwa implementasi model problem-based learning pada pembelajaran muatan IPS memberikan pengaruh yang positif terhadap keterampilan berpikir kritis peserta didik. Hal ini didukung oleh data hasil penelitian terkait impementasi model PBL dimana respon peserta didik pada keterlaksanaan model ini masuk dalam kategori baik, dengan persentase perolehan sebesar $80,86 \%$.

Adapun hasil pada penelitian ini sejalan dengan tujuan penggunaan model PBL yang telah dikemukakan oleh Trianto (2009: 94-95) dimana PBL memiliki salah satu tujuan yakni membantu peserta didik mengembangkan keterampilan berpikir dan keterampilan pemecahan masalah. Hal ini didukung oleh hasil penelitian yang dilakukan hasil penelitian yang dilakukan oleh Rizal Abdurrozak, dkk (2016) yang menyatakan bahwa terdapat peningkatan kemampuan berpikir kreatif siswa dengan menggunakan model PBL. Selain itu, didukung pula oleh hasil penelitian yang dilakukan oleh Herzon (2018: 45) yang menyatakan bahwa problem-based learning terbukti signifikan dalam meningkatkan keterampilan berpikir kritis peserta didik sehingga pembelajaran menjadi efektif dan efisien.

Dixon (dalam Alghafri \& Nizam, 2014: 519) menjelaskan berpikir kritis adalah sebuah kebiasaan untuk bisa membuka diri dalam menganalisis, mensintesis, dan mengevaluasi informasi untuk memecahkan suatu permasalahan. Pencapaian yang baik dari berpikir kritis 
peserta didik dalam mempelajari muatan IPS pada khususnya, dipengaruhi oleh beberapa faktor. Adapun sejumlah faktor yang mempengaruhi keterampilan berpikir kritis peserta didik telah dikemukakan oleh Muhibbin (2009: 145-146) yaitu faktor internal yang meliputi keadaan ataupun kondisi yang terdiri dari jasmani dan rohani, faktor eksternal yang meliputi kondisi lingkungan peserta didik, dan faktor pendekatan belajar (approach to learning) yaitu, jenis upaya peserta didik yang meliputi strategi dan metode yang digunakan untuk melakukan kegiatan pembelajaran materi-materi pelajaran.

\section{SIMPULAN}

Berdasarkan data hasil penelitian dan pembahasan, dapat disimpulkan bahwa implementasi model Problem Based Learning memberikan pengaruh terhadap keterampilan berpikir kritis peserta didik pada muatan IPS kelas V di SDN 30 Ampenan Tahun Pelajaran 2019/2020. Hal tersebut dibuktikan oleh perolehan nilai signifikansi sebesar 0,00 yang berarti nilai signifikansi kurang dari 0,05 maka dinyatakan $\mathrm{H}_{0}$ ditolak dan $\mathrm{H}_{\mathrm{a}}$ diterima. Selain itu, hasil analisis regresi linier sederhana pada koefisien determinasi (R Square) diperoleh sebesar 0,644. Hasil tersebut menunjukkan bahwa terdapat pengaruh implementasi model Problem Based Learning terhadap keterampilan berpikir kritis peserta didik dengan persentase besarnya pengaruh sebesar $64,4 \%$.

\section{DAFTAR PUSTAKA}

Abidin, Yunus. 2014. Desain Sistem Pembelajaran Dalam Konteks Kurikulum 2013. Bandung: Refika Aditama.

Abdurrozakk, dkk. 2016. Pengaruh Model Problem Based Learning Terhadap Kemampuan Berpikir Kreatif Siswa. Jurnal Pena Ilmiah: Vol. 1 No. 1

Alghafri, dkk. 2014. The Effect of Integrating Creative and Critical Thinking on Schools Students Thinking. International Journal of Social Science and Humanity: Vol.4, No.6

Anisaunnafi'ah, Rifka. 2015. Pengaruh Model Problem Based Learning Terhadap Motivasi Belajar IPS Pada Siswa Kelas IV SD Negeri Grojongan. Universitas Negeri Yogyakarta.

Arikunto, Suharsimi. 2010. Prosedur Penelitian: Suatu Pendekatan Praktek. Jakarta: Rineka Cipta.

Assegaff, Asrani. Dkk. 2016. Upaya Meningkatkan Kemampuan Berpikir Analitis Melalui Model Problem Based Learning. Jurnal Pendidikan: Hal 38.48 
Erfan, M., \& Ratu, T. (2018). Pencapaian HOTS (Higher Order Thinking Skills) Mahasiswa Program Studi Pendidikan Fisika FKIP Universitas Samawa. Jurnal Pendidikan Fisika Dan Teknologi, 4(2), 208. https://doi.org/10.29303/jpft.v4i2.831

Herzon, Hayuna. 2018. Pengaruh Problem Based Learning (PBL) Terhadap Keterampilan Berpikir Kritis. Jurnal Pendidikan: Vol. 3 Hal 42-46.

Hidayati, dkk. 2008. Pengembangan Pendidikan IPS SD. Jakarta: Direktorat Jenderal Pendidikan Tinggi Departemen Pendidikan Nasional.

Kholida, Diana. 2015. Pengaruh Penggunaan Model Pembelajaran Problem Based Learning Terhadap Motivasi Belajar Siswa. Universitas Negeri Semarang.

Maulyda, M. A., Hidayati, V. R., Rosyidah, A. N. K., \& Nurmawanti, I. (2019). Problemsolving ability of primary school teachers based on Polya's method in Mataram City. PYTHAGORAS: Jurnal Pendidikan Matematika, 14(2), 139-149. https://doi.org/https://doi.org/10.21831/pg.v14i2.28686

Maulyda, M. A., Radiusman, R., Erfan, M., Darmiany, D., \& Asrin, A. (2020). The effectiveness of the use lecture journal books in improving learning outcome of PGSD Student's. Premiere Educandum: Jurnal Pendidikan Dasar Dan Pembelajaran, 10(1), 1. https://doi.org/10.25273/pe.v10i1.5183

Muhibbin, Syah. 2009. Psikologi Belajar. Jakarta: PT Grafindo Persada

Nugraha, Widdy. 2018. Peningkatan Kemampuan Berpikir Kritis dan Penguasaan Konsep IPA Siswa SD Dengan Menggunakan Model Problem Based Learning. Jurnal Pendidikan Dasar: Vol.10 No.2 Hal. 120

Priyatno, Duwi. 2010. Paham Analisis Statistika Data dengan SPSS. Yogyakarta: Mediacom. Sudjana, Nana. 2005. Dasar-Dasar Proses Belajar Mengajar. Bandung: Sinar Baru Algesindo. Sugiyono. 2018. Metode Penelitian Kombinasi (Mixed Methods). Bandung: Alfabeta CV. Sukroni. 2014. Pengaruh Model Problem Based Learning Terhadap Keterampilan Berpikir Kritis Siswa SDN 1 Sajira Pada Mata Pelajaran IPA Konsep Ekosistem. Universitas Islam Negeri Syarif Hidayatullah Jakarta.

Syamsuddin dan Vismaia, D. 2011. Metode Penelitian Pendidikan Bahasa. Bandung: PT Remaja Rosdakarya.

Trianto. 2009. Mendesain Model Pembelajaran Inovatif Progresif. Jakarta: Kencana.

Wijaya, C. 2010. Pendidikan Remedial: Sarana Pengembangan Mutu Sumber Daya Manusia. Bandung: PT Remaja Rosdakarya. 
Laswita, dkk. (2020). Pengaruh Implementasi Model...

Yulianti, D.I., dan Khanafiyah, S. 2011. Pembelajaran Fisika Berbasis Hand On Activities Untuk Menumbuhkan Kemampuan Berpikir Kritis dan Meningkatkan Hasil Belajar Siswa SMP. Jurnal Pendidikan Fisika Indonesia, Vol. 7 